\title{
PROAKTÍVNE ZVLÁDANIE ZÁŤAŽE U PACIENTOV S ISCHEMICKOU CHOROBOU SRDCA
}

\author{
Andrea Solgajová1, Gabriela Vörösová1, Tomáš Sollár², Dana Zrubcová1, \\ Rastislav Rosinský ${ }^{3}$ \\ ${ }^{1}$ Katedra ošetrovatel'stva FSVaZ UKF Nitra \\ asolgajova@ukf.sk,gvorosova@ukf.sk, dzrubcova@ukf.sk \\ ${ }^{2}$ Ústav aplikovanej psychológie, FSVaZ, UKF v Nitre \\ tsollar@ukf.sk \\ 3 Ústav romologických štúdií, FSVaZ, UKF v Nitre \\ rrosinsky@ukf.sk
}

\begin{abstract}
Abstrakt: Východiská: Proaktívne zvládanie patrí k adaptívnym formám zvládania zát'ažových situácií a je zamerané na udržanie, či zlepšenie kvality života. Proaktívne správanie môže napomáhat' jednotlivcom upevnit' si psychosociálnu adaptáciu, napríklad na ochorenie u pacientov s ischemickou chorobou srdca (ICHS).

Ciel': V príspevku zist'ujeme rozdiely v proaktívnom zvládaní zát’aže u pacientov s ICHS podl'a pohlavia a vzt'ahy proaktívneho zvládania, veku a osobnosti pacientov s ICHS.

Metódy: Výberový súbor tvorilo 30 respondentov s diagnózou ICHS (I20 - I25), z toho bolo 14 žien a 16 mužov. Vekový priemer bol 61,07 roku. Pre hodnotenie proaktívneho zvládania bola použitá slovenská verzia Greenglassovej dotazníku PCI (Proactive Coping Inventory) a pre hodnotenie osobnostných charakteristík dotazník Mini IPIP (International Personality Item Pool). Výskum bol schválený etickou komisiou nemocnice.

Výsledky: Zistili sme významné rozdiely v proaktívnom riešení situácií medzi mužmi a ženami, s vyšším zastúpením u mužov. Vyšší vek koreluje s nižším proaktívnym zvládaním pacientov sischemickou chorobou srdca. Proaktívne riešenie situácií súvisí s vyššou emocionálnou stabilitou, extraverziou a svedomitost'ou ako osobnostnými vlastnost’ami.

Implikácie: V procese starostlivosti je potrebné poznat' schopnost' adaptácie na ochorenie a spôsoby zvládania. Proaktívne zvládanie je zamerané na zlepšenie kvality života, preto je vel'mi prospešné. Mužské pohlavie, vyšší vek a osobnostné charakteristiky emocionálna stabilita, extraverzia a svedomitost' sú faktory, ktoré s ním úzko súvisia.
\end{abstract}

Kl'účové slová: Proaktívne zvládanie. Vek. Osobnost'. Pohlavie. Ischemická choroba srdca.

\section{ÚVOD}

Lazarus a Folkman (1984, p. 141) definujú zvládanie ako „neustále meniaca sa kognitívna a behaviorálna snaha riadit' špecifické vonkajšie a/alebo vnútorné požiadavky, ktoré sú považované za namáhavé, alebo presahujúce prostriedky danej osoby“. Táto definícia naznačuje, že zvládanie môže pozostávat' z niekol'kých prispôsobení, ktoré prebiehajú simultánne alebo sekvenčne. $\mathrm{V}$ počiatočnej fáze zdravotnej krízy, vyhýbanie alebo odmietanie ako stratégie zvládania, môžu byt' niekedy výhodou; ak sú však dlhodobejšie, sú vo všeobecnosti nepriaznivé. Autori Lazarus a Folkman (1984) popisujú dve formy stratégií zvládania zát'aže: zvládanie zamerané na problém (človek sa zameriava na situáciu, pričom má (konštruktívnu) snahu hl'adat' spôsoby ako ju zmenit', prípadne sa jej v budúcnosti vyhnút') a zvládanie orientované na emócie (kedy sa človek 
zameriava na zmiernenie prežívaných emócií, ktoré vznikli v dôsledku stresu, pričom k zmene situácie nemusí dôjst'). Túto teóriu doplnili autori Schwarzer, Taubert (2002) o časový aspekt, čo formulovali v koncepcii proaktívneho zvládania zát’aže. Podstata tohto prístupu spočíva v anticipácii pôsobenia stresora a riešenia situácie pred nástupom a rozvojom stresovej situácie. Ciel'om koncepcie bolo vytvorit' pozitívne orientovaný spôsob zvládania zát’aže, vychádzajúci zo stanovenia ciel'ov a usilovanie sa o ich zvládnutie ešte pred plným nástupom vplyvu stresora (Greenglassová, 2001).

V oblasti psychológie zdravia sú vel'mi významné tzv. kognitívne modely v zvládaní ochorenia pacientom. Tieto modely kladú dôraz na myšlienkovú kognitivitu. Príkladom môže byt' napríklad model sebaovládanie alebo sebariadenia. Tento model do určitej miery chápe zvládanie ochorenia ako riešenie daného problému. Znamená to, že pacient vníma svoje príznaky ochorenia, ale vytvára si svoje vlastné predstavy o ochorení. Pre neho riešenia problému znamená dosiahnutie normálneho zdravotného stavu. Zdravotný stav je chápaný ako norma a akékol'vek odchýlky sú chápané ako problémy, ktoré treba akútne riešit'. Motiváciou pre pacienta sú práve tieto odchýlky od normy (Křivohlavý, 2002).

Na Slovensku sa srdcovocievne ochorenia podiel'ajú na celkovej úmrtnosti $53 \%$ a sú jednou z hlavných príčin kratšej strednej dížky života u nás. Vzhl'adom na častý výskyt ischemickej choroby srdca je podl'a niektorých autorov potrebné venovat' oblast' výskumu možným patofyziologickým a psychologickým faktorom (Frasure-Smith, 1991; Šedová et al., 2016), najmä tým, ktoré sú modifikovatel'né (ovplyvnitel'né). V súčasnosti nemajú pacienti dostatok informácii o možných rizikových faktoroch od lekárov, či od sestier (Olišárová et al., 2016), pričom oblast' ohl'adom zníženie stresu ako významného rizikového faktora býva často diskutovanou oblast'ou v prevencii kardiovaskulárnych ochorení. Pre podporu edukácie v oblasti rizikových faktorov pri kardiovaskulárnych ochoreniach by zohrávala rolu aj komunitná starostlivost' (Tóthová et al., 2014). Zvládanie je stabilizačný faktor, ktorý jednotlivcom napomáha upevnit’ si psychosociálnu adaptáciu počas stresujúceho obdobia; zahŕňa kognitívne a behaviorálne úsilie na zníženie alebo odstránenie stresujúcich podmienok a asociatívnej emocionálnej úzkosti. Sarason et al. (1990) uvádzajú, že medzi pacientmi, ktorí sa zotavujú zo srdcových ochorení, sa stratégia - zvládanie zamerané na riešenie problému pozitívne spája s kvalitou života a stratégia - vyhýbanie, sa v neskoršom období negatívne spája s kvalitou života. Vo všeobecnosti sa uvádza, že stratégie zvládania zát'aže sú spojené s dosiahnutými zdravotnými výsledkami u pacientov (Chalfont, Bennett, 1999; Svensson et al., 2016), a preto je potrebné pre dosiahnutie pozitívnych výsledkov v procese starostlivosti a liečby podporit' prístupy pre zvládnutie náročnej situácie a pre zlepšenie komunikácie s pacientom (Buetow, Goodyear-Smith, Coster, 2001). Ak pacient bojuje so svojím ochorením, nevie ho adaptívne zvládnut', môže to viest' ešte k zhoršeniu jeho zdravia, nie pozitívnym zmenám celkového zdravotného stavu. Dochádza nielen k biologickým zmenám, rovnako ako aj k zmene sociálnej role, čo nie je pre neho priaznivé (Zacharová, 2007). Podl'a uvedenia Greenglasovej (2002) je proaktívne zvládanie multidimenzionálne a zamerané do budúcna a spája v sebe procesy zamerané na udržanie, či zlepšenie kvality života.

Variabilita vnímania stresovej situácie a vol'ba stratégií zvládania zát’aže u pacientov so srdcovocievnym ochorením môže byt' ovplyvnená viacerými faktormi. Vplyv pohlavia na zvládanie zátaže u pacientov s ischemickou chorobou srdca uvádzajú viacerí autori (Bogg, Thornton,, Bundred, 2000), ako aj vzt'ah s osobnost’ou (Šolcová, Tomanek, 1994; Chalfont, Bennett, 1999; Crawshaw, Auyeung, Norton, Weinman, 2016), d'alej s vekom, či dížkou ochorenia (Buetow, Goodyear-Smith, Coster, 2001).

Ciel'om výskumu bolo zhodnotit' proaktívne zvládanie zát’aže u mužov a žien s ischemickou chorobou srdca, zistit’ vzájomný vzt’ah proaktívneho zvládania, veku a osobnosti u pacientov $\mathrm{s}$ ischemickou chorobou srdca. 


\section{METÓDY}

Výberový súbor tvorilo $\mathrm{n}=30$ pacientov s lekárskou diagnózou ischemická choroba srdca ( I20 I25 podl'a MKCH-10), z toho 16 (53,3\%) mužov a 14 (46,7 \%) žien. Zarad'ujúcimi kritériami boli: vek nad 18 rokov, hospitalizácia min. 3 dni, ochota spolupracovat' a informovaný súhlas $\mathrm{s}$ výskumom. Vek respondentov bol od 32 do 82 rokov $\left(\mathrm{M}_{\mathrm{vek}}=61,07 ; \mathrm{SD}_{\mathrm{vek}}=13,26\right)$.

Greenglassovej dotazník PCI (Proactive Coping Inventory) bol použitý pre hodnotenie proaktívneho zvládania. Použili sme slovenskú verziu dotazníka, ktorú adaptovali autori Sollár, Romanová (2011). Dotazník obsahuje 55 položiek, ktoré sú štruktúrované do 7 subškál: Proaktívne riešenie situácií (14 položiek), Reflektívne riešenie situácií (11 položiek), Strategické plánovanie (4 položky), Preventívne zvládanie situácií (10 položiek), Vyhl'adávanie inštrumentálnej opory (8 položiek), Vyhl'adávanie emočnej opory (5 položiek) a Vyhýbanie sa riešeniu situácie (3 položky). Položky majú charakter oznamovacích viet a sú hodnotené na štvorbodovej škále (vôbec nie je pravda, takmer nie je pravda, trochu pravda, úplná pravda) (Šolcová, Lukavský, Greenglassová, 2006). Presvedčenia jednotlivcov s vysokým skóre v škálach proaktívneho zvládania obsahujú bohatý potenciál pre zmenu, ktorá vyúst'uje do zlepšenia seba samého a svojho okolia (Sollár, Romanová, 2011).

Dotazník Mini IPIP (International Personality Item Pool) ako sebavýpoved'ový dotazník bol použitý na hodnotenie piatich osobnostných charakteristík (faktorov). Vychádza z modelu Big Five (Teória vel'kej pät'ky). Prostredníctvom dotazníka je možné hodnotit' extraverziu, neurotizmus, otvorenost', prívetivost' a svedomitost'. Obsahuje 20 položiek, pre každý faktor osobnosti 4 položky. Hodnotenie prebieha na Likertovej škále od 1 do 5 , kde 1 je vôbec nevystihuje a 5 úplne vystihuje (Hullová, Ďuriš, 2017).

Ide o prierezový dizajn výskumu. Výskum bol realizovaný vo Fakultnej nemocnici v Nitre na Kardiologickej klinike od decembra 2016 do februára 2017 po schválení Etickou komisiou. Zber dát bol realizovaný sestrou, ktorá bola pre použitie oboch meracích nástrojov zaškolená.

Pre spracovanie výsledkov bol použitý štatistický program IBM SPSS 24.0. Výsledky sme hodnotili pomocou deskriptívnych štatistík mediánu (Mdn), priemernej hodnoty (AM) a smerodajnej odchýlky (SD). Rozdiely sme posudzovali Mann-Whitneyho U testom a vzt'ahy sme skúmali Pearsonovým koeficientom súčinovej korelácie (r).

\section{VÝSLEDKY}

V jednotlivých subškálach dotazníka PCI sme zistili štatisticky významné rozdiely medzi mužmi a ženami. Konkrétne v subškále Proaktívne riešenie situácií $(\mathrm{p}=0,006)$, ktoré bolo viac zastúpené u mužov $(A M=44,73)$ ako žien $(A M=37,31)$; d’alej v subškále Vyhl'adávanie emočnej podpory ( $p$ $=0,016)$, ktoré bolo viac zastúpené u žien $(A M=13,03)$ ako mužov $(A M=16,62)$; a v subškále Vyhýbanie sa riešeniu situácie $(p=0,046)$ viac zastúpené u žien $(A M=9)$ ako u mužov(AM = 6,87) (tab. 1). 
Tab. 1 Rozdiely v proaktívnom zvládaní u pacientov s ischemickou chorobou srdca podl'a pohlavia

\begin{tabular}{|l|c|c|c|c|c|c|c|c|}
\hline & \multicolumn{7}{|l}{$\begin{array}{l}\text { Muži } \\
\mathbf{n}=15\end{array}$} & \multicolumn{2}{l|}{$\begin{array}{l}\text { Ženy } \\
\mathbf{n}=\mathbf{1 3}\end{array}$} \\
\cline { 2 - 11 } & Mdn & AM & SD & Mdn & AM & SD & U & p \\
\hline Proaktívne riešenie situácií & 44 & 44,73 & 7,176 & 35,5 & 37,31 & 5,407 & 37,5 & $\mathbf{0 , 0 0 6}$ \\
\hline Reflektívne riešenie situácií & 26,5 & 26,53 & 6,501 & 27 & 27,85 & 6,149 & 87,5 & 0,644 \\
\hline Strategické plánovanie & 9 & 9,27 & 3,127 & 10,2 & 10,15 & 2,115 & 77,5 & 0,353 \\
\hline $\begin{array}{l}\text { Preventívne zvládanie } \\
\text { situácií }\end{array}$ & 23,67 & 24,33 & 4,152 & 26 & 26,23 & 4,764 & 77,5 & 0,356 \\
\hline $\begin{array}{l}\text { Vyhl'adávanie } \\
\text { inštrumentálnej opory }\end{array}$ & 20,67 & 20,4 & 4,687 & 23 & 23,62 & 3,686 & 59,5 & 0,079 \\
\hline $\begin{array}{l}\text { Vyhl'adávanie emočnej } \\
\text { opory }\end{array}$ & 13,8 & 13,93 & 2,865 & 17 & 16,62 & 2,501 & 45,5 & $\mathbf{0 , 0 1 6}$ \\
\hline $\begin{array}{l}\text { Vyhýbanie sa riešeniu } \\
\text { situácie }\end{array}$ & 6,25 & 6,87 & 3,137 & 9 & 9 & 1,683 & 54,5 & $\mathbf{0 , 0 4 6}$ \\
\hline
\end{tabular}

Legenda: $n$ - absolútna početnost'; Mdn - medián; AM - aritmetický priemer, SD - smerodajná odchýlka, U štatistický faktor, $p$ - hodnota pravdepodobnosti

V rámci skúmania vzt’ahu subškál dotazníka PCI a veku sme zistili štatisticky významné v dvoch subškálach. Štatisticky významný negatívny vzt'ah proaktívneho riešenia situácií s vekom ( $\mathrm{r}=$ 0,688, p < 0,001); d’alej štatisticky významný pozitívny vzt'ah vyhýbanie sa riešeniu situácie $\mathrm{s}$ vekom $(\mathrm{r}=0,469, \mathrm{p}<0,05)($ tab. 2$)$.

Tab. 2 Vzt'ah medzi proaktívnym zvládaním a vekom pacientov s ischemickou chorobou srdca

\begin{tabular}{|l|l|}
\hline & Vek \\
\hline Proaktívne riešenie situácií & $\mathbf{- 0 , 6 8 8 * *}$ \\
\hline Reflektívne riešenie situácií & $-0,094$ \\
\hline Strategické plánovanie & $-0,184$ \\
\hline Preventívne zvládanie situácií & $-0,161$ \\
\hline Vyhl'adávanie inštrumentálnej opory & 0,1 \\
\hline Vyhl'adávanie emočnej opory & 0,318 \\
\hline Vyhýbanie sa riešeniu situácie & $\mathbf{0 , 4 6 9 *}$ \\
\hline
\end{tabular}

Legenda: koeficient súčinovej korelácie $\left(\mathrm{r}_{\mathrm{s}}\right) ;{ }^{*} \mathrm{p}<0,05 ;{ }^{* *} \mathrm{p}<0,01$

V rámci skúmania vzt’ahu subškál dotazníka PCI a osobnostných charakteristík sme zistili viacero štatisticky významných vzt'ahov. S osobnostnou charakteristikou Neurotizmus negatívny vztah vykazovali subškály Proaktívne riešenie situácií $(r=-0,490, p<0,001)$ a Preventívne zvládanie situácií $(r=-0,412, p<0,05)$. Štatisticky významný pozitívny vzt'ah vykazoval neurotizmus so subškálou Vyhýbanie sa riešeniu situácia $(r=0,400, p<0,05)$. Extraverzia vykazovala štatisticky významný pozitívny vzt’ah s proaktívnym riešením situácií $(\mathrm{r}=0,578, \mathrm{p}<0,001)$ a negatívny vzt’ah s vyhýbaním sa riešeniu situácie $(r=-0,537, p<0,001)$. Osobnostná charakteristika Otvorenost' a Prívetivost' štatisticky významne korelovali s preventívnym zvládaním situácie ( $\mathrm{r}=$ $0,414, p<0,05 ; \mathrm{r}=0,571, \mathrm{p}<0,001)$. Najviac štatisticky významných vzt’ahov vykazovala 
osobnostná charakteristika Svedomitost' a to nasledovne: s proaktívnym zvládaním situácií ( $\mathrm{r}=$ 0,592, $\mathrm{p}<0,001)$; so strategickým plánovaním $(\mathrm{r}=0,441, \mathrm{p}<0,05)$; s preventívnym zvládaním situácií $(r=0,464, p<0,05)$ a s vyhýbaním sa riešeniu situácie $(r=-0,409, p<0,05)$ (tab. 3$)$.

Tab. 3 Vzt’ah medzi proaktívnym zvládaním a osobnostnými charakteristikami pacientov $\mathrm{s}$ ischemickou chorobou srdca

\begin{tabular}{|l|c|c|c|c|c|}
\hline & $\mathbf{N}$ & $\mathbf{E}$ & $\mathbf{0}$ & $\mathbf{P}$ & $\mathbf{S}$ \\
\hline Proaktívne riešenie situácií & $\mathbf{- 0 , 4 9 0}$ & $\mathbf{\mathbf { 0 , 5 7 8 } ^ { * * }}$ & 0,136 & 0,269 & $\mathbf{0 , 5 9 2}^{* *}$ \\
\hline Strategické plánovanie & $-0,304$ & 0,344 & 0,178 & 0,219 & $\mathbf{0 , 4 4 1}^{*}$ \\
\hline Preventívne zvládanie situácií & $\mathbf{- 0 , 4 1 2 ^ { * }}$ & 0,287 & $\mathbf{0 , 4 1 4}^{*}$ & $\mathbf{0 , 5 7 1}$ & $\mathbf{0 , 4 6 4}^{* *}$ \\
\hline $\begin{array}{l}\text { Vyhl'adávanie inštrumentálnej } \\
\text { opory }\end{array}$ & $-0,127$ & 0,091 & $-0,068$ & 0,326 & 0,177 \\
\hline Vyhl'adávanie emočnej opory & 0,021 & $-0,003$ & $-0,240$ & 0,088 & 0,006 \\
\hline Vyhýbanie sa riešeniu situácie & $\mathbf{0 , 4 0 0}^{*}$ & $-\mathbf{0 , 5 3 7 * *}$ & 0,107 & 0,012 & $\mathbf{- 0 , 4 0 9}^{*}$ \\
\hline
\end{tabular}

Legenda: koeficient súčinovej korelácie $(r){ }^{*} p<0,05 ;{ }^{* *} p<0,01 ; N-$ neurotizmus, $E$ - extraverzia, $O$ otvorenost', $P$ - prívetivost', $S$ - svedomitost'

\section{DISKUSIA}

Vo výskume sme sa zamerali na skúmanie zvládania ako stabilizačného faktora, ktorý by mal jednotlivcom napomáhat' upevnit' si psychosociálnu adaptáciu počas stresujúceho obdobia, akou môže byt' ochorenie. Zamerali sme sa na skupinu pacientov s ischemickou chorobou srdca, pričom samotné ochorenie a situácie s ním spojené, ako napríklad možné zmeny v ekonomickom stave, $\mathrm{v}$ rolovom statuse a rolových funkciách predstavujú stres. Pre dosiahnutie pozitívnych výsledkov v procese starostlivosti a pre dosiahnutie compliance pacientov je potrebné podporit' prístupy pre zvládnutie náročnej situácie (Buetow, Goodyear-Smith, Coster, 2001). Vo všeobecnosti sa uvádza, že ak pacient bojuje so svojím ochorením, nevie ho efektívne zvládnut', môže to viest' ešte k zhoršeniu jeho zdravia (Zacharová, 2007). Podl'a uvedenia Greenglasovej (2002) je práve proaktívne zvládanie zamerané na udržanie, či zlepšenie kvality života, pričom nároky a riziká sú pomenované ako ciele, ku ktorým jedinec smeruje. Ide o teóriu zvládania zát'aže, ktorú predstavili Schwarzer a Taubert (2002), pričom predstavili alternatívu riešenia zátažovej situácie na základe časovej dimenzie a to vzmysle takom, že rozlišujú medzi reaktívnym, anticipačným, preventívnym a proaktívnym zvládaním. Reaktívne zvládanie smeruje do minulosti a anticipačné, preventívne a proaktívne je nasmerované do budúcnosti. Proaktívne zvládanie je ešte na rozdiel od preventívneho formulované pozitívne a zamerané na dosiahnutie ciel’ov. Preventívne zvládanie je zamerané na prekonávanie stresogénnych situácií. Autori d'alej uvádzajú, že proaktívne zvládanie je výnimočné najmä tým, že zahŕňa (budúce) požiadavky, ktoré môžu potenciálne viest' $\mathrm{k}$ d'alšiemu sebarozvoju.

Podl'a uvedenia viacerých autorov je vnímanie stresovej situácie a zvládanie zát'aže ovplyvnené pohlavím (Bogg, Thornton,, Bundred, 2000), vekom (Buetow, Goodyear-Smith, Coster, 2001) a aj typom osobnosti (Šolcová, Tomanek, 1994; Chalfont, Bennett, 1999; Crawshaw, Auyeung, Norton, Weinman, 2016). 
Ciel'om nášho výskumu bolo zhodnotit' proaktívne zvládanie zát’aže u mužov a žien s ischemickou chorobou srdca, zistit' vzájomný vzt'ah proaktívneho zvládania, veku a osobnosti u pacientov $\mathrm{s}$ ischemickou chorobou srdca.

V troch subškálach dotazníka PCI (proaktívne riešenie situácií, vyhl'adávanie emočnej podpory a vyhýbanie sa riešeniu situácie) sme zistili štatisticky významné rozdiely medzi mužmi a ženami. Proaktívne riešenie situácií bolo viac zastúpené u mužov, Vyhl'adávanie emočnej podpory a Vyhýbanie sa riešeniu situácie bolo viac zastúpené u žien. Šolcová, Lukavský, Greenglassová, (2006) skúmali zvládanie zát’aže prostredníctvom dotazníka PCI u bežnej populácii, pričom tiež zistili štatisticky významné rozdiely medzi mužmi a ženami. Tieto rozdiely boli v škálach reflektívneho riešenia situácií a vo vyhl'adávaní emočnej opory. Ženy viac využívali pre zvládanie zát'ažovej situácie vyhl'adávanie emočnej opory, čo sa tiež potvrdilo aj našimi zisteniami u pacientov s ischemickou chorobou srdca. Rovnaké zistenie štatisticky významného rozdiely vo vyhl'adávaní emočnej opory uvádzajú aj autori Greenglassová, Schwarzer, Taubert (1999). Títo autori zistili štatisticky významný rozdiel aj vo vyhl'adávaní inštrumentálnej opory medzi mužmi a ženami, pričom $\mathrm{v}$ skupine pacientov $\mathrm{s}$ ischemickou chorobou srdca sme rozdiel $\mathrm{v}$ tejto subškále dotazníka PCI nezistili.

Autori Bogg, Thornton, Bundred (2000), ktorí skúmali pacientov po infarkte myokardu uvádzajú, že zvládanie zát’aže sú rozdielne medzi mužmi a ženami. Ženy po prekonaní infarktu myokardu vykazovali vyššie emocionálne t’ažkosti, horšiu kvalitu života. Tieto zistenia naznačujú potrebu podpory proaktívneho prístupu riešenia situácií u žien.

Ďalej sme zistili štatisticky významný negatívny vzt’ah proaktívneho riešenia situácií a veku pacienta, tzn. väčšie využívanie proaktívneho zvládania u mladších pacientov. Naopak vyhýbanie sa riešeniu situácie súviselo viac s vyšším vekom u pacientov s ischemickou chorobou srdca.

V bežnej populácii v skupine seniorov v českej populácii boli zistené iba slabé korelácie subškál reflektívne riešenie situácií a strategické riešenie situácií s vekom. (Lukavský, Šolcová, Preiss, 2011). Autori d’alej uvádzajú, že u seniorov zistili nižšie hodnoty v subškále proaktívne riešenie situácie v porovnaní s mladými respondentmi, čo podporujú aj naše zistenia.

Na základe týchto zistení, by bolo vhodné podporit’ práve proaktívne zvládanie situácií u starších l'udí. Podl'a autorov Ouwehand, de Ridder, Bensing (2007) sa predpokladá, že proaktívny prístup riešenia situácií je dôležitým prvkom úspešného stárnutia a umožňuje starším l'ud'om spokojnejšie prekonávat' problémy. Dokonca koncept proaktívneho zvládania bol použitý ako východisko pre programy prípravy na starnutie (Bode, de Ridder, Bensing, 2006). Výskumnými zisteniami je podporené tvrdenie, že proaktívne zvládanie koreluje pozitívne s funkčnou nezávislost'ou a negatívne s depresiou u seniorov (Greenglassová, Fiksenbaum, Eaton, 2006), a zároveň vedie k menšiemu množstvu t’ažkostí a somatizácii (Fiksenbaum, Greenglassová, Eaton, 2006).

V rámci skúmania vzt’ahu zvládania zát'aže a osobnostných charakteristík sme zistili viacero štatisticky významných vzt'ahov, čo potvrdzuje aj štúdia (Hambrick, Mc Cord, 2010).

Proaktívne riešenie situácií súviselo negatívne s neurotizmom, tzn. čím je pacient s vyšším neurotizmom, tým menej využíva proaktívne riešenie situácií. Podl'a zistení výskumu autorov Connor-Smith and Flachsbart (2007) neurotizmus je prediktor maladaptívneho zvládania zát’aže. Ruisel (2008) uvádza, že u l'udí s neurotizmom je znížená možnost' adaptácie na životné požiadavky. Naopak l'udia opačného typu osobnosti budú voči týmto zmenám odolnejší, a majú charakteristické črty ako optimizmus, zmysel pre koherenciu alebo nezdolnost'. Podl'a uvedenia autorov Šolcová, Tománek (1994) a Wiebe and McCallum (1986) osoby s vysokou odolnost'ou, resp. emocionálnou stabilitou majú tendenciu viac využívat’ efektívne stratégií zvládania zát’aže. 
Pacienti s touto osobnostnou črtou vo väčšej miere dodržiavajú odporúčanú životosprávu správnu výživu, viac cvičenia, menej využívanie návykových látok.

Ďalej sme zistili, že čím je pacient väčší extrovert a svedomitý, tým viac využíva proaktívne zvládanie. Aj podl'a Connor-Smith and Flachsbart (2007) extraverzia a svedomitost' súvisí s adaptívnym zvládaním zátaže, najmä so zvládaním zameraným na problém. Podl'a Ruisela (2008) osobnostná črta osobnosti typický extrovert sa pokúša chápat' a interpretovat' rôzne stránky vonkajšieho sveta. Smeruje k logickému mysleniu, usiluje o život podl'a pevných pravidiel. Extrovert je praktický a objektívny. Svedomití l'udia sú ciel'avedomí a spol'ahliví, so silnou vôl'ou, preto sa dokážu lepšie prispôsobit’ zmenám v súvislosti s ochorením a idú za svojim (novým) ciel'om.

Zaujímavým zistením bolo, že vyhl'adávanie inštrumentálnej opory a vyhl'adávanie sociálnej opory nevykazovali vzt'ahy so žiadnou osobnostnou charakteristikou.

\section{ZÁVER}

Zistili sme štatisticky významné rozdiely v proaktívnom riešení situácií medzi mužmi a ženami, s vyšším zastúpením u mužov. Vo vzt'ahu proaktívneho zvládania a veku sme zistili štatisticky významný vzt’ah, pričom vyšší vek pacientov s ischemickou chorobou srdca vykazoval vztah s menšou preferenciou proaktívneho zvládania. Ďalej sme zistili, že proaktívne riešenie situácií súvisí s emocionálnou stabilitou, extraverziou a svedomitost'ou. V procese starostlivosti je potrebné poznat' schopnost' adaptácie na ochorenie a spôsoby zvládania. Proaktívne zvládanie je zamerané na zlepšenie kvality života, preto je vel'mi prospešné. Podpora adaptívnych foriem zvládania náročnej situácie je potrebná pre dosiahnutie pozitívnych výsledkov v procese starostlivosti a liečby.

\section{LITERATÚRA}

Bode, C., de Ridder, D. T., \& Bensing, J. M. (2006). Preparing for aging: Development, feasibility and preliminary results of an educational program for midlife and older based on proactive coping theory. Patient Education and Counseling, 61(2), 272-278.

Bogg, J., Thornton, E., \& Bundred, P. (2000). Gender variability in mood, quality of life and coping following primary myocardial infarction. Coronary Health Care, 4(4), 163-168.

Buetow, S., Goodyear-Smith, F., \& Coster, G. (2001). Coping strategies in the self-management of chronic heart failure. Family Practice, 18(2), 117-122.

Crawshaw, J., Auyeung, V., Norton, S., \& Weinman, J. (2016). Identifying psychosocial predictors of medication non-adherence following acute coronary syndrome: A systematic review and metaanalysis. Journal of Psychosomatic Research, 90(11), 10-32.

Connor-Smith, J. K., \& Flachsbart, C. (2007). Relations between personality and coping: A metaanalysis. Journal of Personality and Social Psychology, 93, 1080-1107.

Fiksenbaum, L. M., Greenglass, E. R., \& Eaton, J. (2006). Perceived social support, hassles, and coping among the elderly. Journal of Applied Gerontology, 25(1), 17-30.

Frasure-Smith, N. (1991). In-hospital symptoms of psychological stress as predictors of long-term outcome after acute myocardial infarction in men. American Journal of Cardiology, 67(2), 121127.

Greenglass, E., (2002). Proactive coping. In E. Frydenberg (Ed.), Beyond coping: Meeting goals, vision, and challenges (pp. 37-62). London: Oxford University Press. 
Greenglass, E. R. (2001). Proactive coping, work stress and burnout. The Journal of the International Stress management Association, 13, 5-8.

Greenglass, E., Fiksenbaum, L., \& Eaton, J. (2006). The relationship between coping, social support, functional disability and depression in the elderly. Anxiety, Stress, and Coping, 19(1), 1531.

Greenglass, E. R., Schwarzer, R., Taubert, S. (1999). The proactive coping inventory (PCI): A multidimensional research instrument. [On-line publication] [vid. 2017-01-12]. Dostupné z: http://www.psych.yorku.ca/greenglass/pci.php.

Hambrick, E. P., \& McCord, D. M. (2010). Proactive Coping and its Relation to the Five-Factor Model of Personality. Individual Differences Research, 8(2), 67-77.

Hullová, D., Duriš, R. (2017). Slovenská verzia dotazníku Mini IPIP. [On-line publication] [vid. 2017-01-12]. Dostupné z: http://ipip.ori.org/newItemTranslations.htm

Chalfont, L., \& Bennett, P. (1999). Personality and coping: their influence on affect and behaviour following myocardial infarction. Coronary Health Care, 3(3), 110-116.

Křivohlavý, J. (2002). Psychologie nemoci. Praha: Grada Publishing.

Lazarus, R. S., \& Folkman, S. (1984). Stress, Appraisal and Coping. New York: Springer Publishing Company.

Lukavský, J., Šolcová, I., \& Preiss, M., (2011). Proaktivní zvládání u osob staršího věku: vztah k vybraným kognitivním proměnným. Československá psychologie, 55(3), 193-203.

Olišárová, V., Šedová, L., Tóthová, V., Bártlová, S., Chloubová, I., Michálková, H., Prokešová, R., \& Trešlová, M., (2016). Areas of health-education of physicians and nurses in care for cardiac patients from the perspective of citizens of the Czech Republic. Neuro Endocrinol Lett., 37(2), 510.

Ouwehand, C., de Ridder, D. T., \& Bensing, J. M. (2007). A review of successful aging models: Proposing proactive coping as an important additional strategy. Clinical Psychology Review, 27, 873-884.

Ruisel, I. (2008). Osobnost' a poznávanie. Bratislava: Ikar.

Sarason, B. R., Sarason, I. G., \& Pierce, G. R. (1990). Social Support: An Interactional View. New York: John Wiley \& Sons.

Schwarzer, R., \& Taubert, S. (2002) Tenacious goal pursuits and striving toward personal growth: Proactive coping. In E. Frydenberg (Ed.), Beyond coping: Meeting goals, visions and challenges (pp. 19-35). London: Oxford University Press.

Sollár T., \& Romanová, M. (2011). Proaktívne zvládania - koncept a súčasný stav merania. In Pomáhajúce profesie - aktuálne trendy v teórii, výskume a praxi. Sekcia 1. Zát’až a odolnost'v pomáhajúcich profesiách (s. 103-130). Nitra: UKF.

Svensson, T., et al. (2016). Coping strategies and risk of cardiovascular disease incidence and mortality: the Japan Public Health Center-based prospective Study. European Heart Journal, 37(11), 890-899.

Šedová, L., Tóthová, V., Olišárová, V., Bártlová, S., Chloubová, I., Michálková, H., Prokešová, R., Trešlová, M., \& Adámková, V. (2016). Opinions regarding the effectiveness of nonpharmacological measures in prevention of cardiovascular disease in the Czech Republic. Neuro Endocrinol Lett. 37(2), 32-38.

Šolcová, I., Lukavský, J., \& Greenglass, E. (2006). Dotazník proaktivního zvládání životních nároků. Československá psychologie, 50(2), 148-162. 
Šolcová, I., \& Tománek, P. (1994). Daily stress coping strategies: an effect of hardiness. Studia Psychologica, 36(5), 390-392.

Tóthová, V., Bártlová, S., Šedová, L., Trešlová, M., Chloubová, I., \& Prošková, E. (2014). The nurse's role in preventive care in the field of community nursing. Neuro Endocrinol Lett, 30(35), 26-33.

Wiebe, D. J.,\& McCallum, D. (1986). Health practices and hardiness as mediators in the stress illness relationship. Health Psychology, 5(5), 425-438.

Zacharová, E., Hermanová, M., \& Šrámková, J. (2007). Zdravotnická psychologie: Teorie a praktická cvičení. Praha: Grada Publishing

Proactive Coping in patients with ischemic heart disease

\section{Abstract}

Background: Proactive coping belongs to adaptive types of coping strategies to stressful events and is oriented on maintaining or raising quality of life. Proactive behaviours can help individuals in strengthening their psychosocial adaptation, including adaptation to situation of patients with ischemic heart disease (IHD).

Objective: Differences in proactive coping in patients with IHD according to gender and relationships of proactive coping to age and personality of patients with IHD are studied.

Methods: The sample consisted of 30 respondents diagnosed with ICHS (I20 - I25), of which 14 were women and 16 men. The average age was 61.07 years. Proactive Coping Inventory (PCI) and the Mini International Personality Item Pool questionnaire (Mini IPIP) were used to assess the proactive coping and personality traits. The research was approved by the ethics committee of the hospital.

Results: Differences in proactive coping strategies between men and women were found with higher use in men. Higher age correlates with lower proactive coping in patients with IHD. Proactive coping is related to higher Emotional stability, Extraversion, and Conscientiousness.

Implications: In the care process, it is necessary to know the ability to adapt to the disease and ways of managing it. Proactive behavior is more typical for patients with different personalities, age and gender. Supporting this kind of behaviors can help patients with IHD in raising their quality of life.

Key words: Proactive coping. Age. Personality. Gender. Ischemic Heart Disease.

\section{Grantová podpora:}

Príspevok bol podporený projektom VEGA 1/0438/16 Osobnostné a situačné prediktory zvládania zát’aže u pacientov s kardiovaskulárnym ochorením a projektom APVV 0532/10 Psychometrická analýza a syntéza existujúcich nástrojov na diagnostikovanie úzkosti a zvládania zát’aže v ošetrovatel'stve. 